\title{
The internal division of the Pliocene Lillo Formation: correlation between Cone Penetration Tests and lithostratigraphic type sections
}

\author{
JEF DECKERS ${ }^{1 *}$, STEPHEN LOUWYE ${ }^{2} \&$ STIJN GOOLAERTS ${ }^{3}$ \\ ${ }^{1}$ VITO, Flemish Institute for Technological Research, Boeretang 200, Mol, Belgium; jef.deckers@vito.be. \\ 2 Paleontology and paleoenvironments, Department of Geology, Ghent University, Krijgslaan 281/S8, Gent, Belgium; \\ stephen.louwye@ugent.be. \\ ${ }^{3}$ OD Earth \& History of Life and Scientific Heritage Service, Royal Belgian Institute of Natural Sciences, Vautierstraat 29, Brussel, \\ Belgium; stijn.goolaerts@naturalsciences.be. \\ corresponding author.
}

\begin{abstract}
The highly fossiliferous Lillo Formation (Pliocene, southern margin North Sea Basin) is formally subdivided in five lithostratigraphical members. While these members are generally relatively easily identifiable in outcrops, they are much more difficultly identifiable in boreholes, hampering geological studies. In the Port of Antwerp area, however, an already existing and dense network of Cone Penetration Tests (CPTs) provides an alternative and additional tool for the recognition of the different lithologies in the Lillo Formation.

CPTs reveal a clear geotechnical threefold division of the Formation. The lower and upper intervals, herein named CPT units Li-A and $\mathrm{Li}-\mathrm{C}$ respectively, are characterized by high $\mathrm{q}_{\mathrm{c}}$ and low $\mathrm{R}_{\mathrm{f}}$ values and correspond to shell-bearing, sandy lithologies. CPT unit LiA can further be divided in a shelly basal subunit Li-A1 and an overlying sandy subunit Li-A2. CPT units Li-A and Li-C are separated by CPT unit Li-B characterized by low $\mathrm{q}_{\mathrm{c}}$ and high $\mathrm{R}_{\mathrm{f}}$ values which correspond to more clayey lithologies.

Four CPTs selected in close vicinity of four well-documented outcrops, some of them being formal stratotypes for the Formation and some of its members, allowed to correlate the geotechnical units with detailed lithological descriptions as well as the formal stratigraphy. CPT unit Li-A1 can be correlated to the Luchtbal Member and the basal part of the Oorderen Member, whereas unit LiA2 corresponds to the superjacent sandy body of the Oorderen Member. The overlying CPT units Li-B and Li-C seem to correlate differently in different outcrops to the clayey upper part of the Oorderen Member, Kruisschans and Merksem Members. This inconsistency hinders any direct correlation between the geotechnical stratigraphy and lithostratigraphy of the Members of the Lillo Formation. Further research is needed to find the reason(s) for this inconsistency.
\end{abstract}

KEYWORDS: CPT units, lithostratigraphy, stratotype sections, Luchtbal Member, Oorderen Member, Kruisschans Member, Merksem Member.

\section{Introduction}

The Lillo Formation (De Meuter \& Laga, 1976) is a highly fossiliferous lithostratigraphic unit that was deposited during the Pliocene (late Zanclean to Piacenzian) along the southern margin of the North Sea Basin (Fig. 1A). It subcrops in the shallow subsurface of northernmost Belgium and in the Port of Antwerp and Campine areas (Fig. 1B). Many temporary outcrops related to the construction of a multitude of docks and locks in the Port of Antwerp area since the 19th century enabled detailed observations of its occurrence, lithology, sedimentary structures, glauconite and fossil content. The type locality of the Lillo Formation as defined by De Meuter \& Laga (1976) is a temporary outcrop related to the construction of the Tijsmanstunnel under the Kanaaldok ('Tunnel Kanaaldok', for location see Fig. 1C). Based on field observations, a review of previously published data and a detailed biostratigraphy by foraminifera, De Meuter \& Laga (1976) formally defined and adhered five members to the Lillo Formation: Luchtbal, Oorderen, Kruisschans, Merksem and Zandvliet. Their referred type sections were the 'Tweede \& Derde Havendok' (Luchtbal Member), the 'Boudewijnsluis' (Oorderen and Kruisschans Members, for location see Fig. 1C), 'Fort van Merksem' (Merksem Member) and the 'Zandvlietsluis' (Zandvliet Member). In the stratotype area, hardly any wireline logs are available that allow correlations between the different type sections of the members or between these type sections and boreholes that penetrate the Lillo Formation in the Campine area. All this hampers the correlation of the different members of the Lillo Formation within and outside the type sections.

However, the Port of Antwerp area is covered by a dense network of Cone Penetration Tests (CPTs) that were carried out during the expansion of the Port of Antwerp area and its road network since the second half of the 20th century. When correlated with boreholes, these CPTs can complement significantly the stratigraphic detail (see also Deckers \& Louwye, 2020, this volume; Schiltz, 2020, this volume). In a recent effort to establish a detailed, parameterized 3D model of the region around Antwerp in an ongoing study (Van Haren et al., in prep.), a large number of CPTs was stratigraphically interpreted for a.o. the Lillo Formation. In an attempt to interpret the different members of the Lillo Formation (excluding the Zandvliet Member) on these CPTs, correlations with nearby type sections in former outcrops were made. The aim of this study is to first establish a subdivision of the Lillo Formation in geotechnical CPT-units and thereafter correlate this subdivision with the lithological descriptions as well as the formal lithostratigraphic subdivision of the Lillo Formation in the type sections. This may help to get better insights in the lateral and vertical facies variability of the Lillo Formation.

\section{Material and methods}

\subsection{Material}

Of the large number of electric CPTs that are available from the Port of Antwerp area, four CPTs were chosen (Fig. 2). Their selection was based on their close proximity to well-described and well-known sections. The first three are in close vicinity of the type section of the Lillo Formation and those of the Oorderen, Kruisschans and Merksem Members, the fourth is located in the close vicinity of the Verrebroekdok section studied in great detail. All CPTs are labeled with their code in the DOV-database (www.dov.vlaanderen.be):

1) GEO-97/138-SM196 is located near the Verrebroekdok section (DOV TO-19990901; Fig. 1C). The temporary outcrop was documented by Goolaerts (2000), both for lithology and sedimentary structures, grain size, glauconite and fossil content. An updated version of the stratigraphic interpretation of this section and some photographs of parts of the section are given in Figures 3, 4 and 5. Samples from the same outcrop were palynologically analyzed by Louwye et al. (2004). This dataset was complemented with field observations made and photographs (Fig. 6) taken at the temporary outcrop for the 


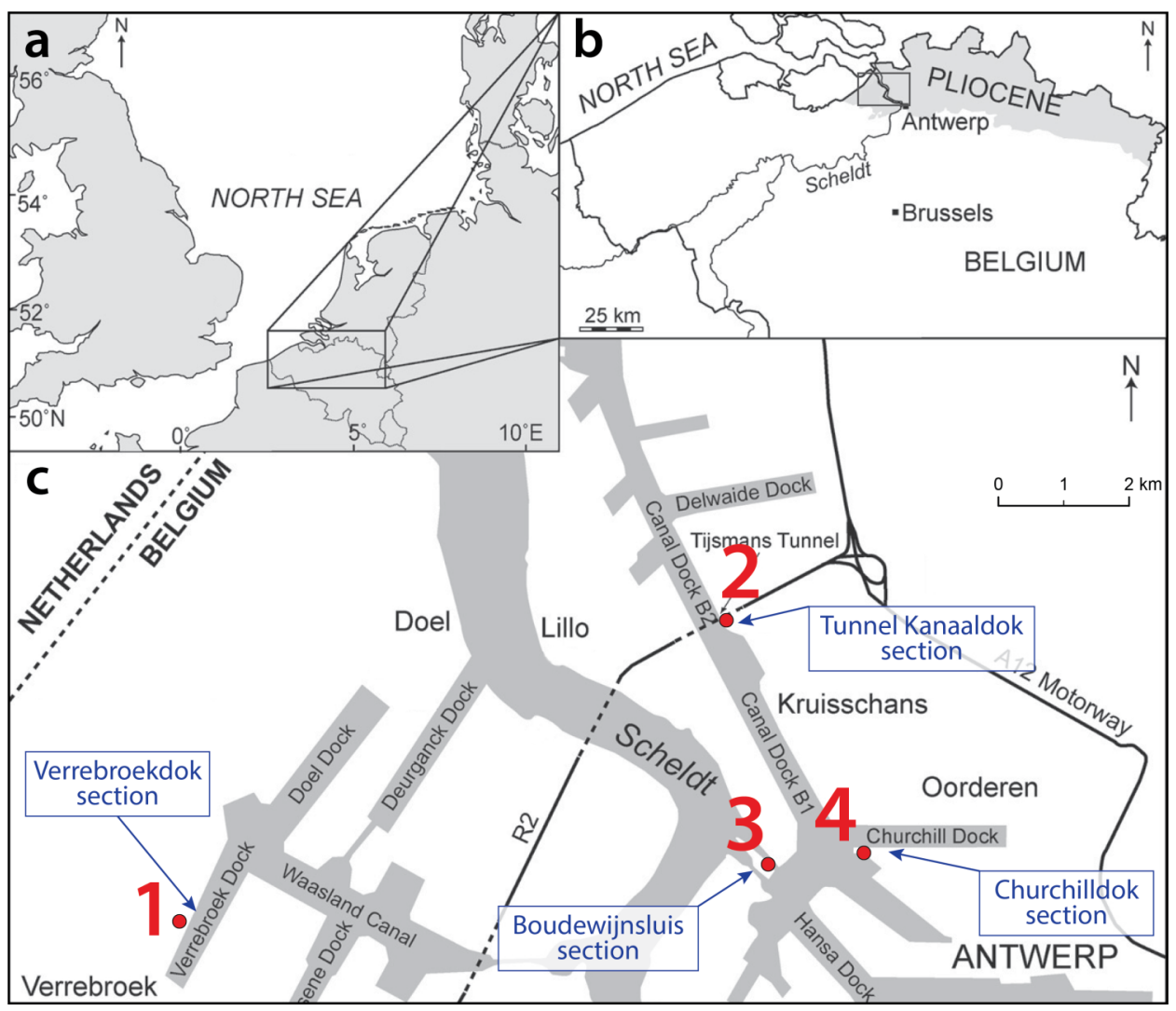

1

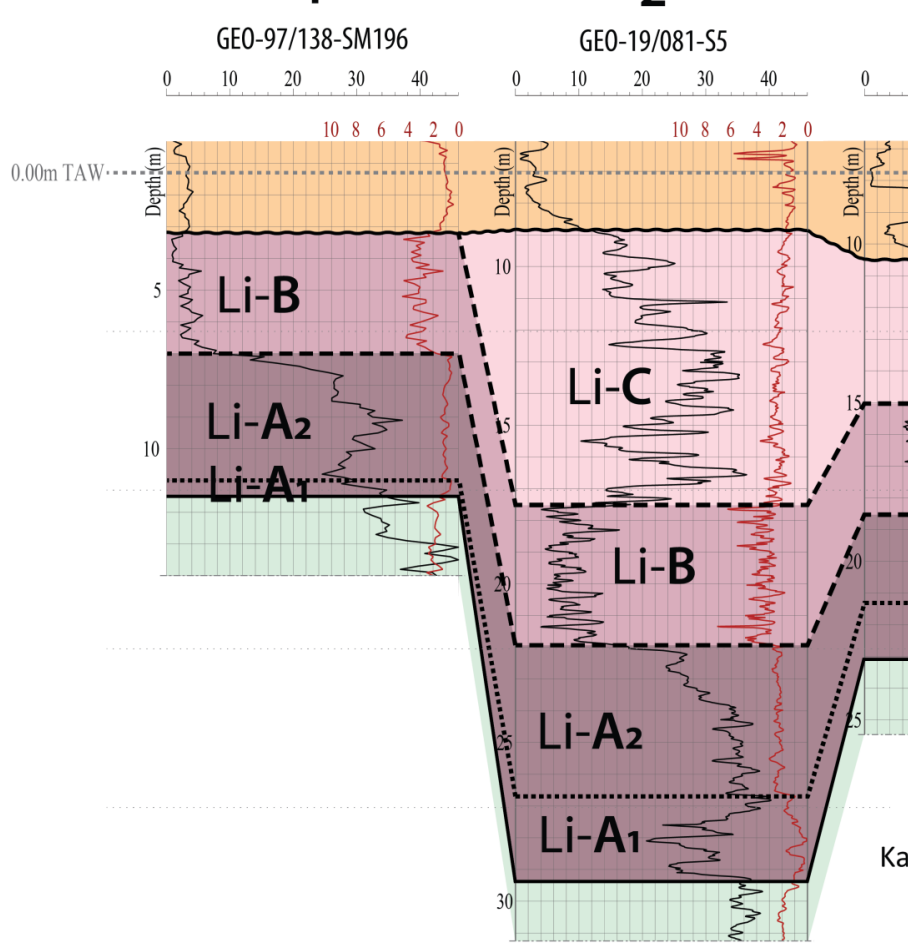

Figure 1. A) Location of the study area in northern Belgium at the southern margin of the North Sea Basin; B) Distribution of marine Pliocene deposits (shaded in gray) in northern Belgium; C) Location of relevant type sections of the Lillo Formation and nearby CPTs for this study in the Antwerp Harbor. Numbers indicate CPTs: $1=$ GEO-97/138SM196; 2= GEO-19/081-S5; 3= GEO-14/112-S6; 4= GEO-06/019S12. This figure was modified after De Schepper et al. (2009).

Figure 2. CPT-correlation profile for the Lillo Formation across the Antwerp Harbor area. The locations of the CPTs on this profile are shown on Figure $1 \mathrm{C}$.

construction of the Deurganckdoksluis (now Kieldrechtsluis; Fig. 1C). The latter was the most recent outcrop in the Port of Antwerp area allowing to study the Lillo Formation in all of its details, in particular of the boundary between the Oorderen and Kruisschans Members.

2) GEO-19/081-S5 is located near the Tunnel Kanaaldok section (DOV BGD015W0304; Fig. 1C) which De Meuter \& Laga (1976) defined as the stratotype section of the Lillo Formation and as a parastratotype for the Luchtbal, Oorderen, Kruisschans and Merksem Members. Samples from this outcrop were studied lithologically (Fig. 7) and analyzed on foraminifera content by Laga (1972). Subsamples were 


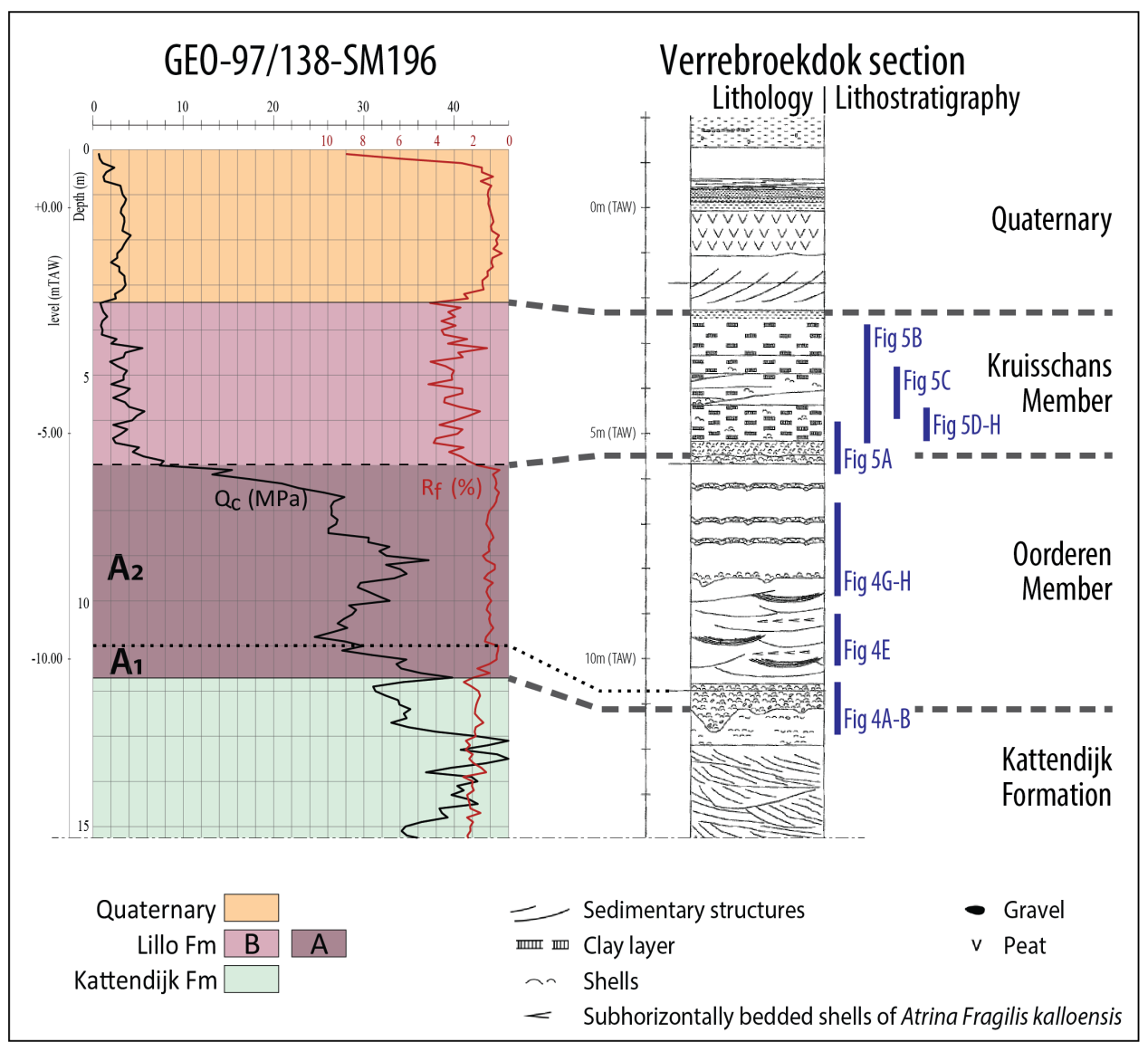

Figure 3. Comparison between a CPT and the CPT units and the litholog and lithostratigraphic interpretations of the temporary outcrop in the Verrebroekdok section of Goolaerts (2000; DOV TO-19990901). For location of this outcrop and the CPT, see Figure 1C. The location of the sections of Figures 4 and 5 is indicated.

palynologically analyzed by De Schepper et al. (2009).

3) GEO-14/112-S6 is located near the Boudewijnsluis section (DOV kb7d15w-B282; Fig. 1C) which was described and biostratigraphically analyzed by de Heinzelin de Braucourt (1952, 1955a, 1955b; Fig. 8), and which De Meuter \& Laga (1976) determined as the stratotype section of both the Oorderen and Kruisschans Members.

4) GEO-06/019-S12 is located near the Churchilldok section (DOV kb7d15w-B285; Fig. 1C) which was described by de Heinzelin de Braucourt (1965; Fig. 9). Additionally, Laga (1972) provided lithological descriptions, lithostratigraphic interpretations and analyzed samples for foraminifera from three sections in the Churchilldok outcrop. From these three sections, the westernmost (L7 II in Laga, 1972; DOV BGD015W0307) lies nearest to GEO-06/019-S12. For this section, the lithostratigraphic interpretations made by Laga (1972) are in good agreement with those described earlier for the entire Churchilldok outcrop by de Heinzelin de Braucourt (1965).

\subsection{Methodology}

First, the Lillo Formation was identified on the abovementioned selection set of CPTs. Intervals of units within the Lillo Formation with similar cone resistances $\left(\mathrm{q}_{\mathrm{c}}\right)$ and friction ratios $\left(\mathrm{R}_{\mathrm{f}}\right)$ were then identified, correlated between the selected CPTs and labelled (Fig. 2), leading to a geotechnical stratigraphy. In a next step, these CPT units were lithologically characterized. This lithological characterization was based on the interpretations of $\mathrm{q}_{\mathrm{c}}$ and $\mathrm{R}_{\mathrm{f}}$ values of the CPT units, but also by correlations of these units with the nearby outcrops that have been described in large detail in literature. These outcrops also represent the type sections for some of the members of the Lillo Formation. So, in a final step, a detailed correlation was attempted between the CPT units and the formal lithostratigraphic units (Figs $3 \&$ 7-9). For this purpose, all data were repositioned in reference to the $0 \mathrm{~m}$ TAW level (TAW: Belgian Ordnance Datum). Note that the CPTs and outcrops are not located at exactly the same spot, but near to each other, which may explain some of the small differences in depth between the boundaries on the CPTs and those described in the outcrops.

\section{Geotechnical stratigraphy (Fig. 2)}

The Lillo Formation in the Port of Antwerp area is typically present on top of the Kattendijk Formation and below continental Quaternary strata. On CPTs, the boundary with the subjacent Kattendijk Formation is typically expressed by a downward change towards very uniform, low $R_{f}$ values, reflecting the homogeneous composition of the latter. In some cases, however, the lower part of the Lillo Formation can also show very uniform, low $R_{f}$ values, in which case the boundary with the Kattendijk Formation is only identifiable by the very low $\mathrm{R}_{\mathrm{f}}$ values in the basal few meter(s) of the Lillo Formation (Li-A1, see below).

The upper boundary with the superjacent Quaternary is typically expressed by a marked decrease in $\mathrm{q}_{\mathrm{c}}$ values. $\mathrm{R}_{\mathrm{f}}$ values on the other hand are rarely useful to pick the boundary with the Quaternary.

The Lillo Formation shows a clear threefold subdivision on CPTs, herein referred to as units Li-A, Li-B and Li-C (Fig. 2). Louwye et al. (2020, this volume) showed that this is also the case for geophysical logs in the Campine area further east. In accordance with this study, the latter authors gave a similar number to the threefold subdivision of the Lillo Formation in geophysical logs.

CPT unit Li-A is characterized by overall high $\mathrm{q}_{\mathrm{c}}$ values of around 30 MPA and low $R_{f}$ values of generally less than $1 \%$. In the uppermost part, the $\mathrm{q}_{\mathrm{c}}$ values of unit $\mathrm{Li}-\mathrm{A}$ tend to decrease. The lower meter(s) of unit Li-A have distinct characteristics 


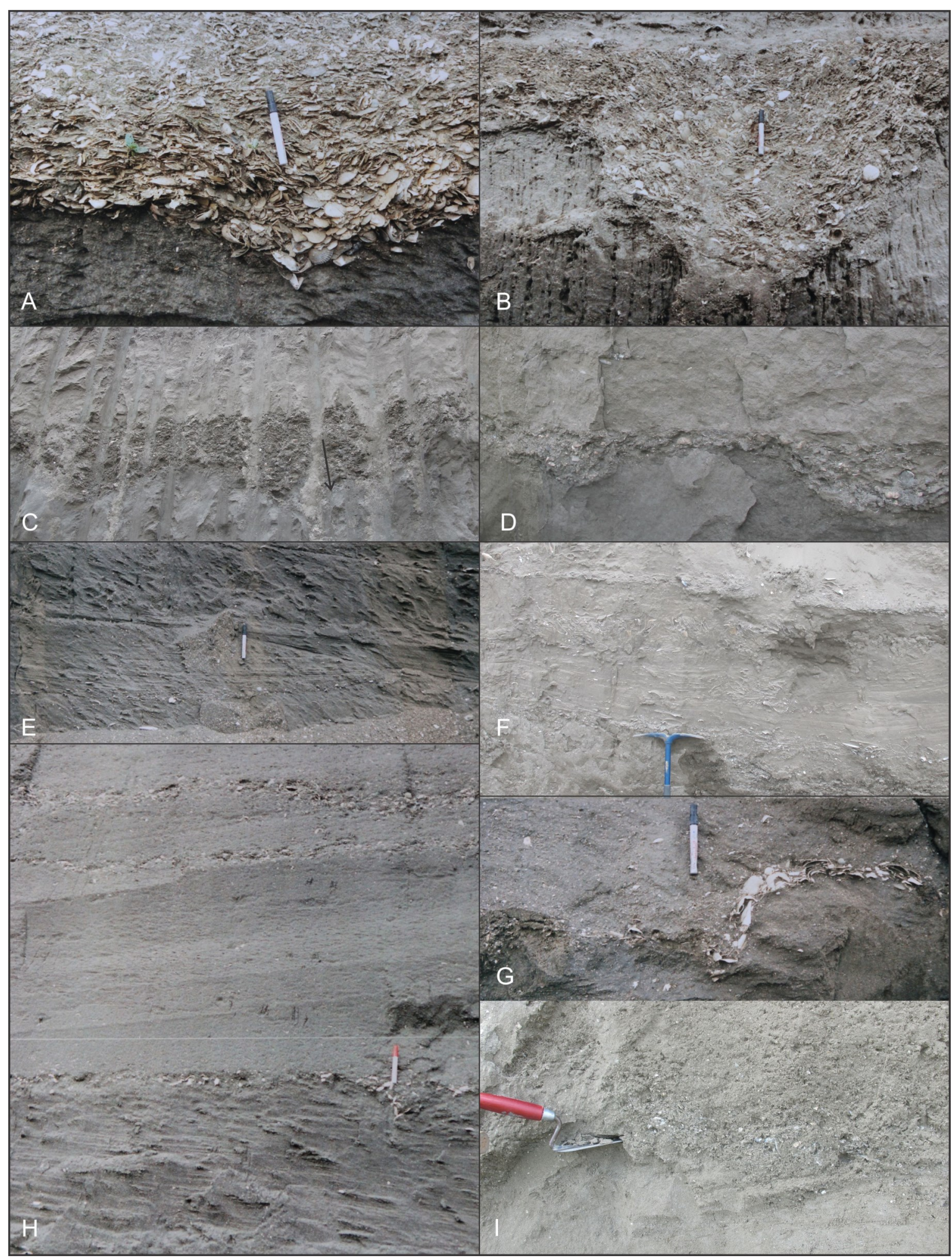

Figure 4. Examples of different lithologies that one may encounter in the Oorderen Member (Lillo Formation). A-B, E, G-H: photos taken by S.G. at temporary outcrop Verrebroekdok in-between July and Dec 1999. C-D, F, I: photos taken by S.G. at temporary outcrop Deurganckdoksluis (now Kieldrechtsluis) in-between Dec 2012 and Sep 2014. Marker pen measures $15 \mathrm{~cm}$, trowel handle $12 \mathrm{~cm}$ and pickaxe blades $33 \mathrm{~cm}$. A-D. A thick and compact interval of clayey sand with pebbles, whale bones and an enormous accumulation of shells named 'Basal Shelly Unit' (BSU) in Louwye et al. (2004) constitutes the base of the Lillo Formation. Both at the Verrebroekdok (A-B) and Deurganckdoksluis (C-D), the lowermost unit of the Lillo Formation, the Luchtbal Member, was absent, and only some reworked shells and yellowish sandstones remind of its original presence. The wavy base of the BSU is caused by load casting (LC), resulting in large variations in thicknesses (from $10 \mathrm{~cm}$ to more than $1 \mathrm{~m}$ ) of the BSU over short distances. When the BSU is marked by large accumulations of Aequipecten shells oriented with their convex side upwards, and wind and rain have washed out its sandy matrix, the change in inclination from subhorizontal to subvertical bedded shells resulting from the load casting can be easily observed (A). D-F, H: Atrina-level (= lower level of the Oorderen Member) displaying crossbedding, temporarily interrupted by storm beds characterized by accumulations of shell grit and subhorizontally bedded V-shaped shells of Atrina fragilis kalloensis. Much rarer, shells of Atrina are still found in their vertical (living) position. G. Load casting in a relatively thin shell bed in the upper part of the Oorderen Member resulting in a vertical displacement of $\sim 20 \mathrm{~cm}$ and nearly vertically bedded shells. H. Interval from the upper part of the crossbedded Atrina-level to the upper part of the Cultellus-level. Three shell beds (SB) are discernable. Load casting was observed in all three of them, albeit less regular than in the BSU. I. Sudden change from sand with low amounts of shell grit to enormous amounts of shell grit. Cultellus-level. 


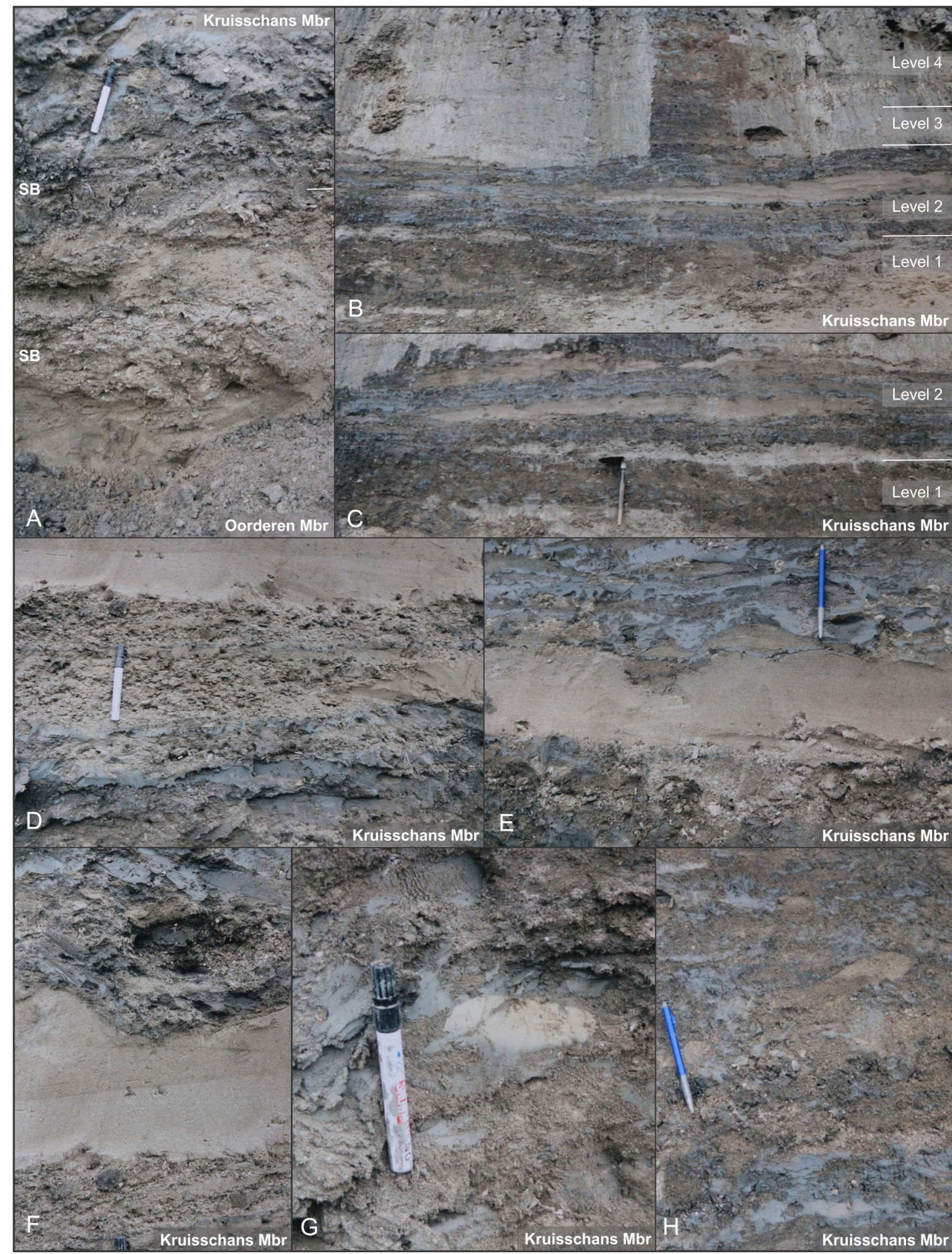

Figure 5. Kruisschans Member lithologies observed at the Verrebroekdok temporary outcrop (photos taken by S.G. in 1999). Abbreviations: Mbr: Member, SB: shell bed. A. Interval from the uppermost part of the Oorderen Member to the lowermost part of the Kruisschans Member. The combination of the presence of large numbers of shells in the uppermost part of the Oorderen Member, load casting of the basal shell bed of the Kruisschans Member and bioturbation piping Kruisschans lithologies down into the top of the Oorderen Member made that the rather sharp boundary appeared sometimes rather gradual. B-C. Succession of lithologies and large-scale sedimentary structures in the Kruisschans Member. Labelling of different levels after Goolaerts (2000). Level 2 sets Level 1 and Level 3 apart by the occurrence of large-scale bodies of laminated sand bodies and lesser disturbed cm-thick bluish-gray layers of pure clay. While Level 4 has lesser amounts of clay, it still differs from the sandier intervals generally attributed to the Merksem Member. D-F. Detailed views on the swiftly changing lithologies and smaller-scale sedimentary structures that can be observed in Level 2. G. Whitish-colored clay lenses are frequently observed in the Kruisschans Member. This example has a sharp upper boundary and a flue lower boundary, where it grades gradually into bluish-gray clay. The whitish color is caused by high amounts of calcareous fragments of coccoliths. H. Detail of how intense bioturbation destroyed many of the primary sedimentary structures. 


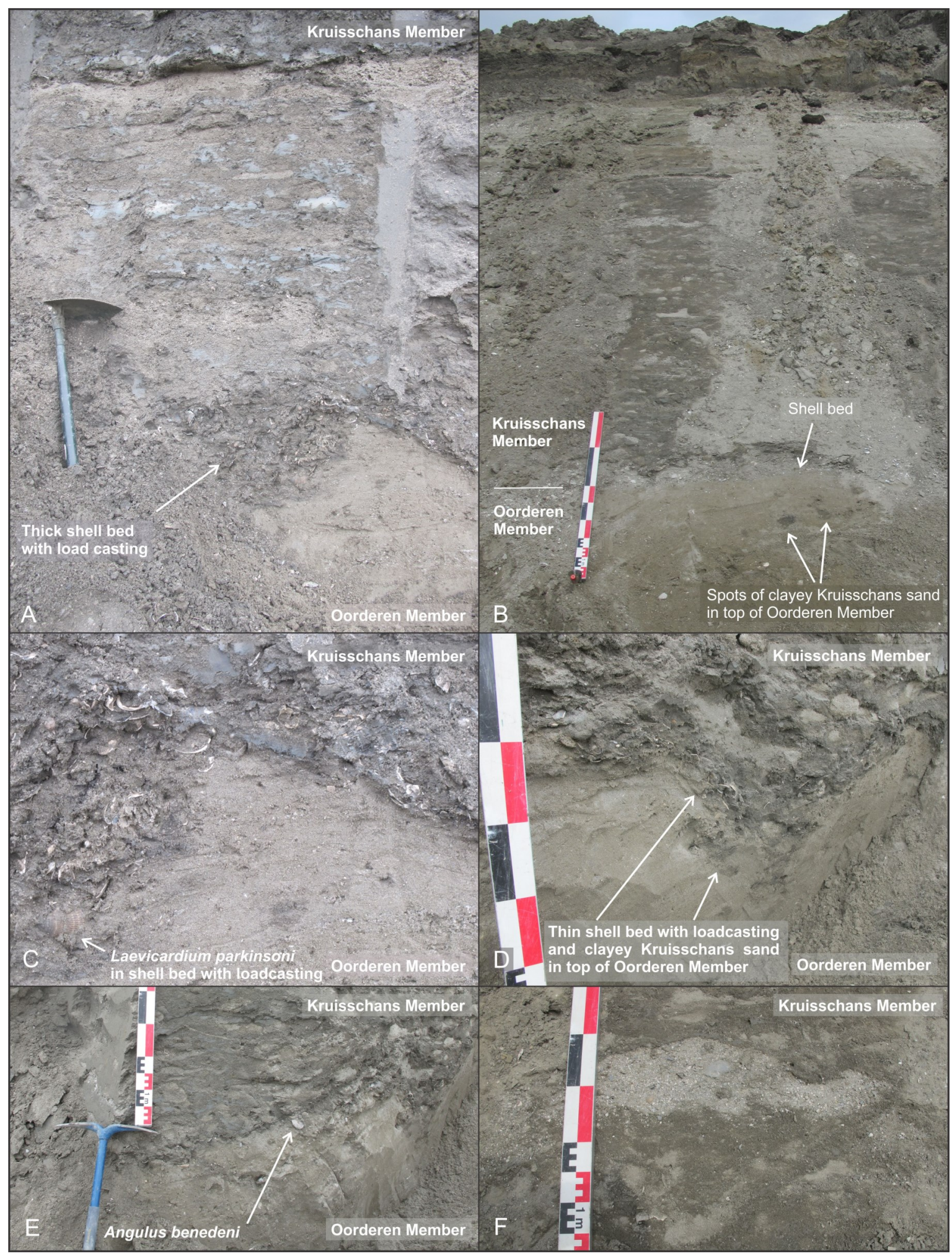

Figure 6. Kruisschans Member lithologies observed at the Deurganckdoksluis temporary outcrop. Photographs taken by S.G. in -between Dec 2012 and Aug 2014. Colored scale bar has 1, 5, 10 and $20 \mathrm{~cm}$ increments. Shovel handle measures $40 \mathrm{~cm}$. A-E. Peculiarities of the contact between the Oorderen and Kruisschans Members. C is an enlargement of A, the load-casting of D is also visible in the extremity of E. A, C and B were taken close to each other along the same NE-SW oriented face, D-F were taken along a NW-SE oriented face roughly $100 \mathrm{~m}$ away from A-C.

The contact between the Oorderen and Kruisschans Members is marked by a sharp transition from clayey sand towards irregular patches of sand, clayey sand and layers of pure clay. Much alike the Verrebroekdok outcrop, the Kruisschans Member starts with a shell bed of varying thickness, from $20 \mathrm{~cm}$ (A) to only $5 \mathrm{~cm}$ (D) to nearly non-existing (E). Load casting (A-D) was identified as the primary cause for the wavy nature of the base of the Kruisschans Member, although that primary erosive surfaces were also identified (E). Load casting also injected irregular flumes of clay into the top of the underlying Oorderen Member (D), and bioturbation, destroying many of the primary sedimentary structures in the Kruisschans Member (A-F) also piped down clayey sand into the top of the Oorderen Member (A, B), resulting sometimes in a more gradual than sharp appearance of the boundary between the Oorderen and Kruisschans Members. Marker bivalve Laevicardium parkinsoni was found in the lower shell bed of the Kruisschans Member (A, C), next to frequently occurring bivalve Angulus benedeni (E). Also much alike Level 4 at the Verrebroekdok outcrop, the uppermost part of the Pliocene sequence below the Holocene peat (B) has a sandier nature, but lacked the large bodies of sand that are generally associated with the Merksem Member. F. Irregularly shaped body of very shelly sand almost devoid of clay within an interval of heavily bioturbated sand and clayey sand. 
with very low $\mathrm{R}_{\mathrm{f}}$ values $(<1 \%)$, the reason for a twofold division into subunits $\mathrm{Li}-\mathrm{A} 1$ and $\mathrm{Li}-\mathrm{A} 2$.

The boundary between units Li-A2 and Li-B coincides with a very strong decrease in $\mathrm{q}_{\mathrm{c}}$ values towards 10 MPA or less and a strong increase in $R_{f}$ values ranging between 2 and $4 \%$. This combination of low $\mathrm{q}_{\mathrm{c}}$ and high $\mathrm{R}_{\mathrm{f}}$ values typically coincides with an increase in clay content. On top of this interval of low $q_{c}$ and high $R_{f}$ values, Li-B is characterized by thin alternations of secondary $\mathrm{q}_{\mathrm{c}}$ and $\mathrm{R}_{\mathrm{f}}$ fluctuations.

The boundary between units Li-B and Li-C coincides with an increase in $\mathrm{q}_{\mathrm{c}}$ values and decrease in $\mathrm{R}_{\mathrm{f}}$ values. This boundary can be either gradual or sharp. Between CPTs, Li-C shows more variations in $\mathrm{q}_{\mathrm{c}}$ and $\mathrm{R}_{\mathrm{f}}$ values compared to $\mathrm{Li}-\mathrm{A}$. These variations cannot be consistently correlated across the Port of Antwerp, indicating lateral facies changes. In general, $\mathrm{Li}$ -C shows an upwards decrease in $\mathrm{R}_{\mathrm{f}}$ values towards $1 \%$ or less. $\mathrm{q}_{\mathrm{c}}$ values fluctuate between the lows of Li-B and highs of Li-A (10-40 MPA) but can also locally reach very high values $(>40$ MPA).

Van Haren et al. (in prep.), who also identified this threefold subdivision in CPTs, noted that unit Li-A gradually thins from almost $8 \mathrm{~m}$ in the north of the Port of Antwerp towards $1 \mathrm{~m}$ or less in the south of the Port of Antwerp. Also in the selection set of CPTs for this study the thickness of Li-A decreases from almost $7 \mathrm{~m}$ in CPT GEO-19/081-S5 near the Tunnel Kanaaldok section in the north of the Port of Antwerp towards about $4.5 \mathrm{~m}$ in CPT GEO-14/112-S6 near the Boudewijnsluis section in the central part of the Port of Antwerp area.

Contrary to unit Li-A, CPT unit Li-B shows more consistent thicknesses of 3-4 m across the entire Port of Antwerp area. As the Lillo Formation and its internal units dip in northern direction across the Port of Antwerp, Li-C shows maximum thicknesses of over $8 \mathrm{~m}$ in the north underneath the Quaternary.

\section{Lithological characterization of the geotechnical stratigraphy}

\subsection{CPT unit $\mathrm{Li}-\mathrm{A}$}

The characteristically low $\mathrm{R}_{\mathrm{f}}$ values of subunit Li-A1 represent coarse material. Correlations with the Tunnel Kanaaldok section show that this subunit represents accumulations of shells, bryozoans and bones in a matrix of sand and with basal gravel (Fig. 7). In the Verrebroekdok section, boulders up to $10 \mathrm{~cm}$ diameter were found in this interval.

The overlying subunit Li-A2 shows higher $\mathrm{q}_{\mathrm{c}}$ and $\mathrm{R}_{\mathrm{f}}$ values which, according to correlations with the type sections and Verrebroekdok section, represents fine to medium, rather homogeneous sand with dispersed shells and shell grit and a limited number of shell beds. The boundary between subunits Li -A1 and Li-A2 coincides with an abrupt increase in $\mathrm{q}_{\mathrm{c}}$ and $\mathrm{R}_{\mathrm{f}}$ values that correlates with a shell layer with some fine gravel (quartz and flint) in the Tunnel Kanaaldok section.

\subsection{CPT unit Li-B}

The sharp boundary between units Li-A and Li-B correlates with a shell layer at the Boudewijnsluis, Churchilldok and Verrebroekdok sections (Figs 3, $7 \& 8$ ). In the Verrebroekdok section (Fig. 3) and Tunnel Kanaaldok section (Fig. 7), the transition between $\mathrm{Li}-\mathrm{A}$ and $\mathrm{Li}-\mathrm{B}$ coincides with the upwards transition from clay in the sand matrix towards clay layers (Laga, 1972; Goolaerts, 2000). In the Churchilldok section, the same transition coincides with an upwards increase in clay content. This increase in clay content from unit Li-A towards unit Li-B agrees with the lower $\mathrm{q}_{\mathrm{c}}$ and higher $\mathrm{R}_{\mathrm{f}}$ values of the latter compared to the first. $R_{f}$ values can also be sensitive to changes in glauconite content. However, glauconite analyses on samples from the Tunnel Kanaaldok section by Laga (1972) and from the Verrebroekdok section by Goolaerts (2000) showed hardy any variations in glauconite content across those parts of the Lillo Formation that correlate with the boundaries between units $\mathrm{Li}-\mathrm{A}, \mathrm{Li}-\mathrm{B}$ and $\mathrm{Li}-\mathrm{C}$.

The characteristic alternations of $\mathrm{q}_{\mathrm{c}}$ and $\mathrm{R}_{\mathrm{f}}$ values within Li$\mathrm{B}$ correlate with alternations of clay and sand layers/lenses. Traces of bioturbation become more apparent in Li-B at the Tunnel Kanaaldok section. Near the Boudewijnsluis section, Li$B$ shows a twofold subdivision, with lower $q_{c}$ and $R_{f}$ values in the upper part (Fig. 8). This boundary within Li-B seems to coincide with the transition from a more homogeneous sediment below to more heterogeneous sediment above.

\subsection{CPT unit Li-C}

At the CPT near the Boudewijnsluis section, the transition from unit $\mathrm{Li}-\mathrm{B}$ towards unit $\mathrm{Li}-\mathrm{C}$ is abrupt and coincides with a strong upwards increase in $\mathrm{q}_{\mathrm{c}}$ values towards 30-40 MPA (Fig. 2). Here, the boundary between Li-B and Li-C coincides with a $\mathrm{q}_{\mathrm{c}}$ spike which represents a gravel layer consistent with sandstones and shell debris (Fig. 8). The overlying first few meters of Li-C contain predominantly high $\mathrm{q}_{\mathrm{c}}$ values which correlate with heterogenous sand layers. At the Tunnel Kanaaldok and Churchilldok sections no gravel was noted at the level corresponding to the base of Li-C (Figs $7 \&$ 9). At the latter sections, the $\mathrm{q}_{\mathrm{c}}$ values within Li-C increase upwards towards a maximum at circa $4 \mathrm{~m}$ above the base. This $\mathrm{q}_{\mathrm{c}}$ increase correlates at the Churchilldok section with a change from heterogeneous sand with many traces of bioturbation and numerous clay laminae and lenses, i.e. the typical facies of the Kruisschans Member similar to the Boudewijnsluis according to de Heinzelin de Braucourt (1965; S.KR. = Sables $d u$ Kruisschans in Fig. 9), towards oblique-stratified fine sands with dispersed shells (C.MK. in Fig. 9). The topping high $\mathrm{q}_{\mathrm{c}}$ values correspond to coarser-grained sands $($ S.GR. $=$ Sables grossiers in Fig. 9) with thin sandstone layers and abundant shell debris. At the Tunnel Kanaaldok section, the increase in $\mathrm{q}_{\mathrm{c}}$ values in the basal part of $\mathrm{Li}-\mathrm{C}$ also correlates with a decrease in frequency of clay layers/lenses and clay matrix within the thicker sand layers. Bioturbation further decreases and crossstratification of the sand layers becomes visible.

At the Boudewijnsluis and Churchilldok sections, only the lower part of Li-C is preserved below the Quaternary (Fig. 2). At the Tunnel Kanaaldok, Li-C is thicker and shows an upper part with upwards decreasing $q_{c}$ and $R_{f}$ values (Fig. 7). This decrease in $\mathrm{q}_{\mathrm{c}}$ values seems to be the result of reduced packing of the sands which was described by Laga (1972) for the top of this section, while the upwards decrease in $R_{f}$ values seems related to his description of reduced clay content of the sands.

\section{Correlation between geotechnical stratigraphy and lithostratigraphy}

\subsection{Verrebroekdok section (Fig. 3)}

- CPT unit Li-A correlates with the Oorderen Member. Subunit Li-A1 correlates to the basal shell bed of the Oorderen Member, named "Basal Shelly Unit" or "BSU" in Louwye et al. (2004). It holds next to an incredible amount of shells (Fig. 4AD) also considerable amounts of clay and gravel. The Luchtbal Member is missing in the Verrebroekdok section (Goolaerts, 2000).

- CPT unit Li-B corresponds to the Kruisschans Member and possible also to the topmost half meter of the Oorderen Member, which has a higher amount of clay than the rest of the Oorderen Member. Remarkably, the change in lithology and sedimentary structures observed throughout the Kruisschans Member (viz. Levels 1-4 on Fig. 5B) do not correspond to major changes in $\mathrm{q}_{c}$ and $\mathrm{R}_{\mathrm{f}}$ values. Only the uppermost part, 
possibly corresponding to Level 4 , shows minor changes, but this may also be the result of weathering of the top of the Pliocene deposits occurring just below the Quaternary.

- CPT unit Li-C was not recognized. Predominantly sandy lithologies were not observed at the Verrebroekdok outcrop by Goolaerts (2000).

\subsection{Tunnel Kanaaldok section (Fig. 7)}

- CPT unit Li-A correlates with the Luchtbal Member and almost the entire Oorderen Member. Subunit Li-A1 correlates with the Luchtbal Member. A subtle $\mathrm{q}_{\mathrm{c}}$ spike at the base of subunit Li-A2 probably corresponds to the basal shell bed of the Oorderen Member, which next to abundant shells and clay also contains gravel. Subunit Li-A2 correlates with the sandy body of the Oorderen Member. The upper boundary of Li-A2 does not perfectly align with the top of the Oorderen Member, which lies about $1.5 \mathrm{~m}$ below the boundary with Li-B. The reason for this mismatch is unknown.

- CPT unit Li-B correlates with the top $1.5 \mathrm{~m}$ of the Oorderen Member and with the entire Kruisschans Member.
The distinction between the uppermost part of the Oorderen Member and the Kruisschans Member in this outcrop was based on the irregular distribution of clay and sand layers/lenses in the latter compared to the homogeneous clayey matrix in the sands of the first (Laga, 1972). The Kruisschans Member transitions into the superjacent Merksem Member as the distinction between clay layers and (less clayey) sand layers becomes more apparent.

- CPT unit Li-C correlates entirely with the Merksem Member. On the CPT as well as in the outcrop itself, the boundary between Li-B and Li-C or the Kruisschans and Merksem Members is sharp.

\subsection{Boudewijnsluis section (Fig. 8)}

- CPT unit Li-A correlates with the Luchtbal Member and lower part of the Oorderen Member. The base of the Luchtbal Member was not attained in this outcrop, but according to the position of the base of CPT subunit Li-A1, it must be located near $-16.5 \mathrm{~m}$ TAW. The boundary with the superjacent Oorderen Member coincides with a shell layer (Glycymeris in

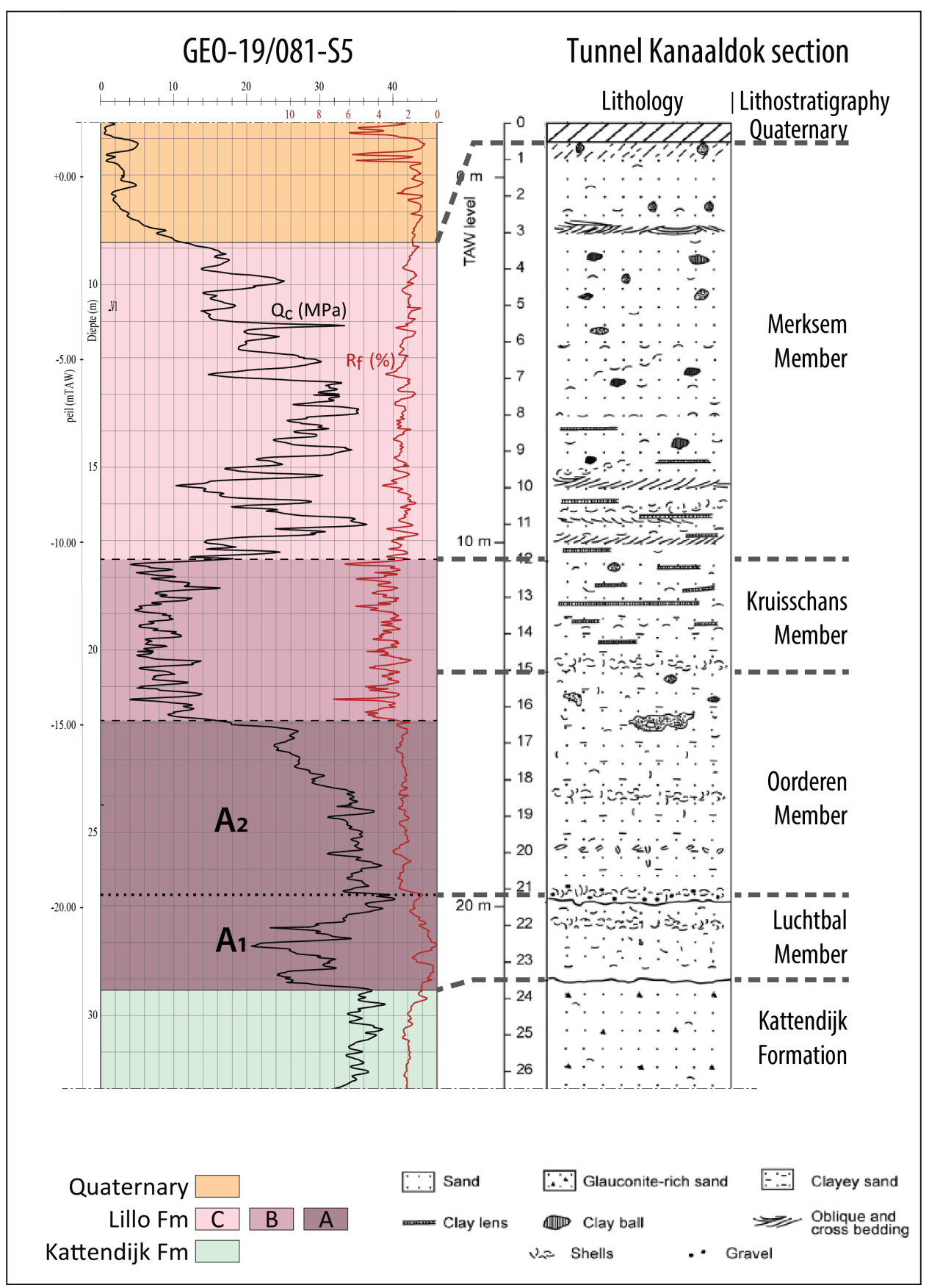

Figure 7. Correlations between a CPT and the stratotype section of the Lillo Formation in the temporary outcrop in the Tunnel Kanaaldok section as shown in De Schepper et al. (2009) based on Laga (1972; DOV BGD015W0304). The depth of the Members of the Lillo Formation is based on De Meuter \& Laga (1976). For location of this outcrop and the CPT, see Figure 1C. 


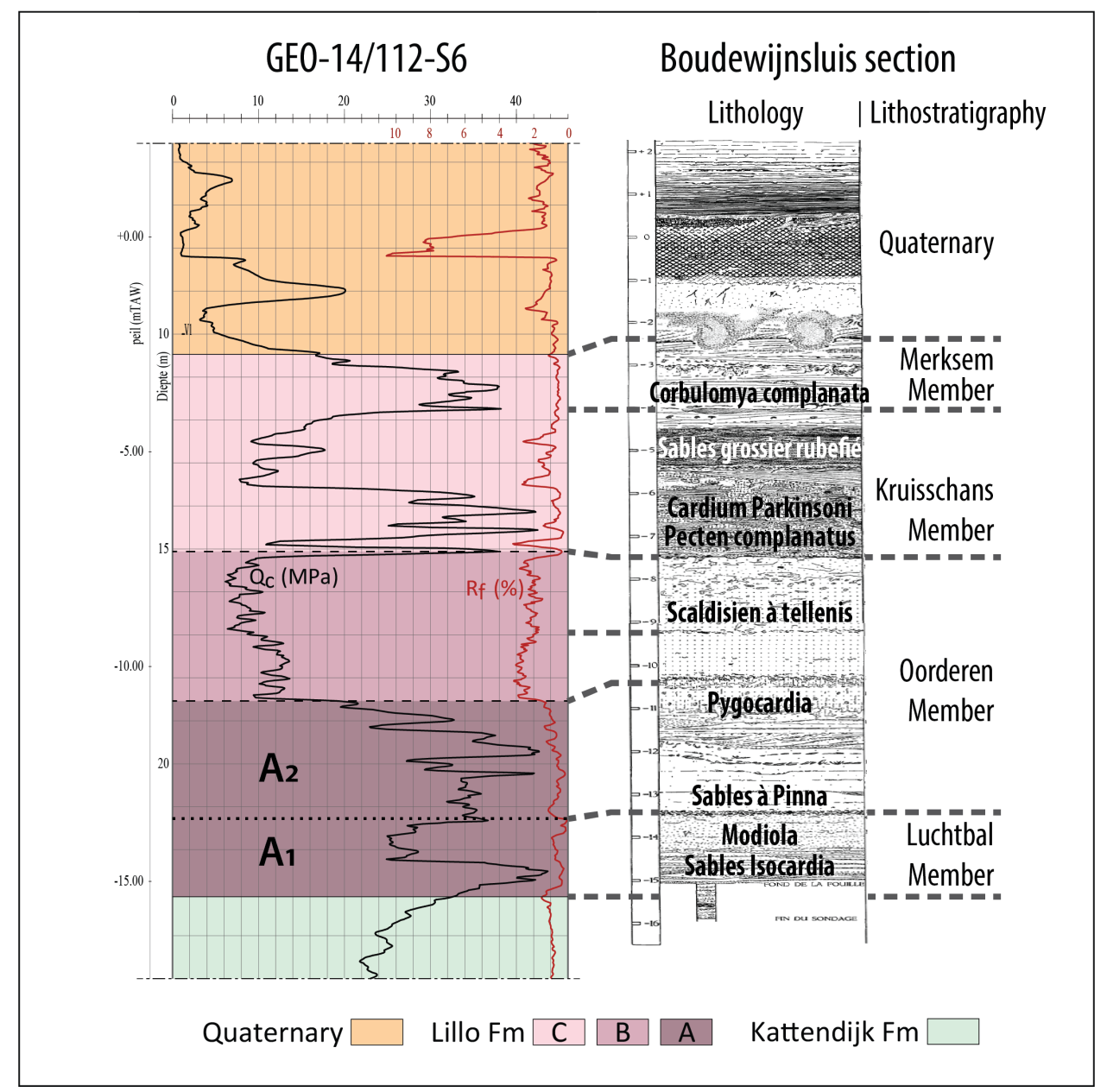

Figure 8. Correlations between a CPT and the temporary outcrop in the Boudewijnsluis as described by de Heinzelin de Braucourt (1955a; DOV kb7d15w -B282). The names on the column of lithology are taken from de Heinzelin de Braucourt (1952). Lithostratigraphic boundaries are after Laga (1972; DOV BGD015W0307). For location of this outcrop and the CPT, see Figure 1C.

de Heinzelin de Braucourt, 1955a). CPT subunit Li-A2 correlates with the lower part of the Oorderen Member.

- CPT unit Li-B correlates with the middle and upper parts of the Oorderen Member.

- CPT unit Li-C correlates with the Kruisschans and Merksem Members. The lower part of Li-C correlates with the Kruisschans Member. De Heinzelin de Braucourt (1955a) describes his 'Zone à Cardium parkinsoni' as a heterogeneous interval with irregular pockets of dark-colored clayey sand, shell -rich gray-greenish sand with oblique stratification and beds and pockets with shell grit. The heterogenous nature of this interval is also well evidenced by a photograph on pl. 2D of de Heinzelin de Braucourt (1955a), and clearly recalls the heterogeneous nature of the Kruisschans Member at the Verrebroekdok section (see also Fig. 5). Shell beds ('Falun CX') mark the base of this interval. De Heinzelin de Braucourt (1955a) interpreted these beds and the gravel they hold as indicative of a transgressive phase. A thin $\mathrm{q}_{\mathrm{c}}$ spike on the CPT correlates with this level. The upper part of Li-C correlates with the Merksem Member. The boundary between the Kruisschans and Merksem Members coincides with a strong upwards increase in $\mathrm{q}_{\mathrm{c}}$ values and the transition towards more uniform $\mathrm{R}_{\mathrm{f}}$ values.

\subsection{Churchilldok section (Fig. 9)}

The Churchilldok section is not a formal parastratotype section, but also shows the typical facies of the Kruisschans and Merksem Members according to de Heinzelin de Braucourt (1965). The first description of this section was carried out by this author, and the litholog is reproduced here in figure 9. Three additional lithologs along different parts of this temporary outcrop were described by Laga (1972), from whom the CPT selected for this study lies the nearest to the westernmost litholog L7 II. In L7II, only a few meters of the Merksem Member were identified below the base of Quaternary deposits. The Oorderen Member was only observed at the base of the section. The following correlations with the CPT units and lithostratigraphy may be proposed (see Fig. 9):

- CPT unit Li-A2 correlates with the lower (less clayey) part of the Oorderen Member (SC.2 = Sables de Kallo glauconifères, homogènes, moins argileux que dessus in Fig. 9).

- CPT unit Li-B correlates with the upper (clay-rich) part of the Oorderen Member. The clay-rich nature of this interval is confirmed by both de Heinzelin de Braucourt (1965) and Laga (1972).

- CPT unit Li-C correlates with both the Kruisschans and Merksem Members. The base of the Kruisschans Member consists of a layer of coarse-grained sand and shells. Contrary to the other sections of the Churchilldok, the shell layer was not well developed in L7 II. The Kruisschans Member represents a heterogeneous mixture of shelly, coarse-grained sand, clayey sand and pure clay lenses, which are expressed as alternation of $\mathrm{q}_{\mathrm{c}}$ highs and lows on the CPT. The boundary with the Merksem Member lies - according to Laga (1972) — at a locally cemented shell layer that correlates closely to the position of a spike in $\mathrm{q}_{\mathrm{c}}$ values on the CPT. The Merksem Member consists of crossstratified, coarse sand which, in agreement with the $R_{f}$ values on the CPT, becomes more homogeneous towards its top. As is the case in the Boudewijnsluis section, the cross-stratified sand of the Merksem Member coincides with high $\mathrm{q}_{\mathrm{c}}$ values and with low, more uniform $\mathrm{R}_{\mathrm{f}}$ values on the CPT compared to the subjacent Kruisschans Member. This is consistent with the decrease in clay content from the latter towards the first. The uppermost part of the Merksem Member is decalcified and 


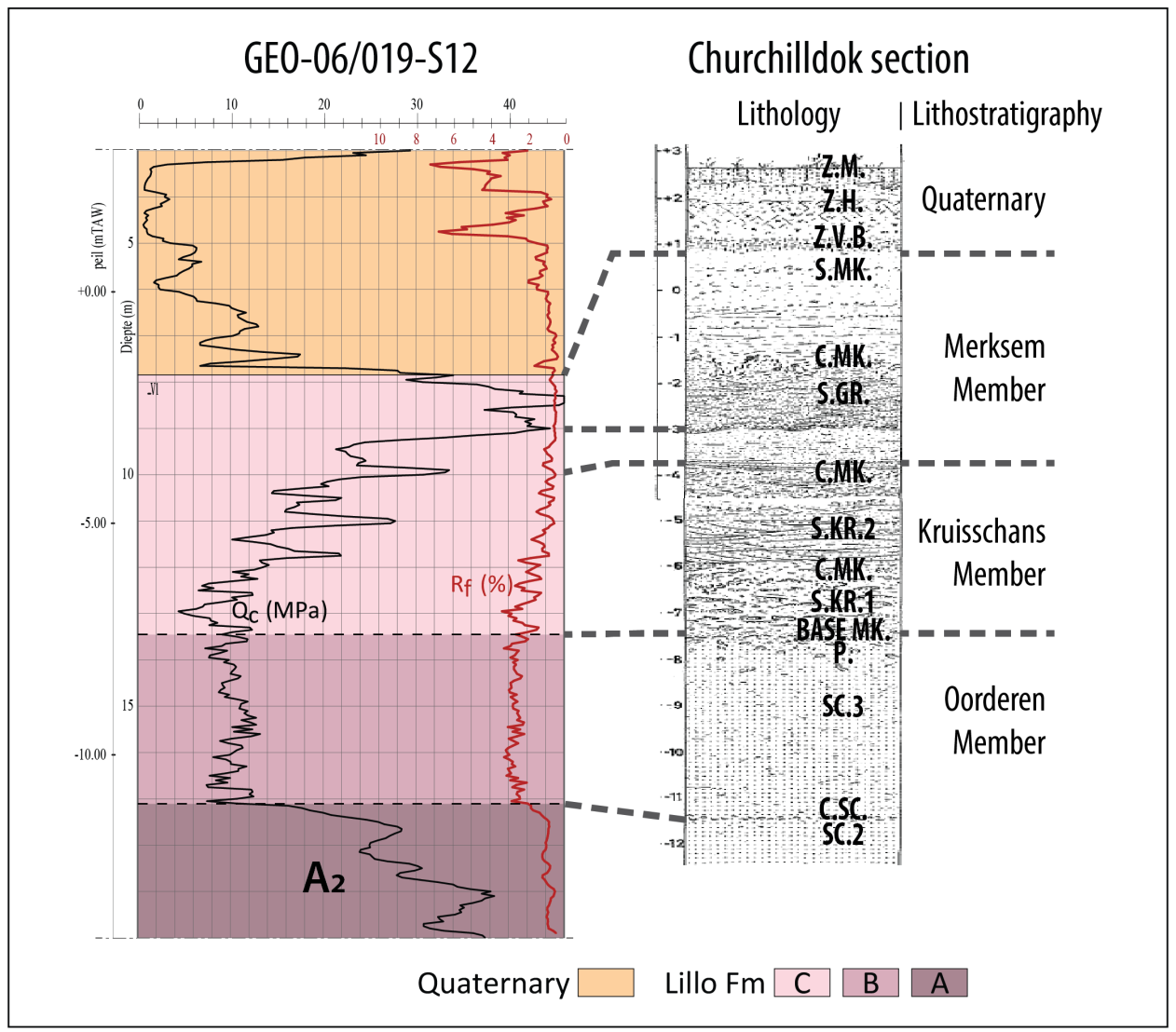

Figure 9. Correlations between a CPT and a well-known section of the Lillo Formation in the Churchilldok temporary outcrop as described by de Heinzelin de Braucourt (1965; DOV kb7d15wB285). Lithostratigraphic boundaries are after Laga (1972). For location of this outcrop and the CPT, see Figure 1C. $\mathrm{C}=$ Horizon coquillier; $\mathrm{P}=$ Grandes pistes et perforations; GR. = Grossier; KR. = Kruisschans; MK. = Merksem; $\mathrm{S}=$ Sables; $\mathrm{SC}=$ Sables de Kallo; Z.H. = Zone de sol humique; Z.M. = Sol brun moderne; Z.V.B. = Zone de sable très gras, vert-bleu.

shows a facies very similar to the one observed near the Zandvlietsluis (i.e. Zandvliet Member; S.MK. = Sables de Merksem décalcifiés in Fig. 9 Sables de Merksem décalcifiés) according to de Heinzelin de Braucourt (1965). On the CPT, this zone is characterized by a sharp decrease in $\mathrm{q}_{\mathrm{c}}$ values, which make it difficult to distinct from the superjacent Quaternary.

\section{Geotechnical stratigraphy versus lithostratigraphy}

Only the lowermost member of the Lillo Formation, the Luchtbal Member, has distinct boundaries (De Meuter \& Laga, 1976). About two meters Luchtbal Member deposits were identified in the outcrop sections of the Boudewijnsluis and Tunnel Kanaaldok (Figs $7 \&$ 8). On nearby CPTs, these deposits consistently correlate with subunit Li-A1. The distinct nature of $\mathrm{Li}-\mathrm{A} 1$ compared to the overlying Li-A2 is mainly the result of the relatively coarse nature of the Luchtbal Member and its boundaries, as it comprises plenty of shells and shell grit. In the Verrebroekdok section, the Luchtbal Member was absent and Li -A1 is only $0.5 \mathrm{~m}$ thick (Fig. 3). In the latter section, Li-A1 is considered as the basal gravel of the Oorderen Member by
Goolaerts (2000) or "Basal Shelly Unit" in Louwye et al. (2004).

The CPTs near and in between the type sections of the Lillo Formation show for the interval above the Luchtbal Member a consistent threefold subdivision into units $\mathrm{Li}-\mathrm{A} 2, \mathrm{Li}-\mathrm{B}$ and $\mathrm{Li}-\mathrm{C}$ (Fig. 2). Correlations with the type sections indicate that unit LiA2 consistently represents the lower, sandy part of the Oorderen Member. The overlying units Li-B and Li-C, on the other hand, do not consistently correlate with the same members of the Lillo Formation in its stratotype and type sections (Fig. 10):

- At the stratotype section of the Oorderen and Kruisschans Members, the Boudewijnsluis section, as well as at the nearby Churchilldok section, unit Li-B correlates with the upper clayey part of the Oorderen Member. In the same sections, the lower part of unit Li-C correlates with the Kruisschans Member and the upper part of unit Li-C with the Merksem Member (Figs 8 \& 9).

- At the stratotype section of the Lillo Formation, the Tunnel Kanaaldok section, as well as at the Verrebroekdok section, unit Li-B correlates with the Kruisschans Member and possibly the topmost part of the Oorderen Member (Figs $3 \&$ 7). In the

\begin{tabular}{|c|c|c|c|c|c|}
\hline \multirow{2}{*}{\multicolumn{2}{|c|}{$\begin{array}{l}\text { Geotechnical } \\
\text { stratigraphy }\end{array}$}} & \multicolumn{4}{|c|}{ Lithostratigraphy } \\
\hline & & Boudewijnsluis & Churchilldok & $\begin{array}{c}\text { Tunnel } \\
\text { Kanaaldok }\end{array}$ & Verreboekdok \\
\hline \multicolumn{2}{|c|}{$\mathrm{Li}-\mathrm{C}$} & $\begin{array}{l}\text { Kruisschans and } \\
\text { Merksem }\end{array}$ & $\begin{array}{c}\text { Kruisschans and } \\
\text { Merksem }\end{array}$ & Merksem & eroded \\
\hline \multicolumn{2}{|c|}{ Li-B } & \multirow[t]{2}{*}{ Oorderen } & \multirow[t]{2}{*}{ Oorderen } & $\begin{array}{l}\text { uppermost } \\
\text { Oorderen and } \\
\text { Kruisschans }\end{array}$ & Kruisschans \\
\hline \multirow{2}{*}{ Li-A } & Li-A2 & & & Oorderen & \multirow{2}{*}{ Oorderen } \\
\hline & Li-A1 & Luchtbal & not reached & Luchtbal & \\
\hline
\end{tabular}

Figure 10. Correlations of the CPT-units (left) with the lithostratigraphic units at the type sections of the Boudewijnsluis, Churchilldok, Tunnel Kanaaldok and Verrebroekdok nearby. 
Tunnel Kanaaldok section, unit Li-C correlates with the Merksem Member (Fig. 7).

Therefore, CPT units and their boundaries do not consistently correlate to the lithostratigraphic units and boundaries as interpreted from observations at temporary outcrops across the Port of Antwerp area. This hinders any direct correlation between the geotechnical stratigraphy and the formal lithostratigraphy. Further research is needed to find out the reason(s) for this inconsistency.

\section{Conclusions}

Four selected CPTs in the Port of Antwerp area revealed a consistent geotechnical threefold subdivision within the Lillo Formation, herein called units Li-A, Li-B and Li-C. Units Li-A and $\mathrm{Li}-\mathrm{C}$ correspond to sandy units with overall high $\mathrm{q}_{\mathrm{c}}$ and low $R_{f}$ values that are separated by a clayey unit Li-B with low $q_{c}$ and higher $R_{f}$ values. Based on the presence of very low $R_{f}$ values in the basal part, Li-A was further divided into a lower subunit Li-A1 and an upper and thicker subunit Li-A2. Whereas units Li-A and Li-B show laterally very similar CPTexpressions, Li-C shows facies changes across the study area.

Being located in close proximity to some of the type sections of the Lillo Formation and its members, a correlation between the abovementioned CPT stratigraphy and the formal lithostratigraphy was achieved. These correlations show that for the lower sandy part of the Lillo Formation (Luchtbal and sandy part of the Oorderen Members), there is a good correlation between the geotechnical units and the lithostratigraphy. Higher upwards in the Lillo Formation, roughly from the moment higher contents of clay are observed (upper part of Oorderen Member), the CPT units do not seem to consistently correlate to the formal stratigraphy.

\section{Acknowledgements}

We gratefully acknowledge financial support from the Bureau for Environment and Spatial Development - Flanders. We would like to thank Katleen van Baelen (VITO) for her excellent work on the figures. Stijn Huyghe and Michiel Dusar are thanked for the constructive discussions on the geotechnical and lithostratigraphic interpretations of the Lillo Formation in the Antwerp area. Katrien De Nil (VPO) and Marleen De Ceuckelaire (RBINS) are thanked for providing the connections between the CPTs and outcrops as discussed in the text with the databases of the Databank Ondergrond Vlaanderen (DOV) and the Geological Survey of Belgium (GSB).

S.G. is grateful to Ir Murielle Reyns, Roger Sieckelink and Nouredine Ouifak of 'Mobiliteit en Openbare Werken (MOW)' for granting access to the Deurganckdoksluis construction site (2012-2014), and to Ir Veerle Schelfhout and all other staff of TV Verrebroek for granting access to the construction site of the Verrebroekdok (1999-2000). Frank Wesselingh (Naturalis), Kristiaan Hoedemakers and Robert Marquet (RBINS) are thanked for valuable discussions on the stratigraphy of the Lillo Formation of the Verrebroekdok and Deurganckdoksluis temporary outcrops. Reviews by Gauthier van Alboom and Noël Vandenberghe led to substantial improvements of the article.

\section{References}

Deckers, J. \& Louwye, S., 2020. The architecture of the Kattendijk Formation and the implications on the early Pliocene depositional evolution of the southern margin of the North Sea Basin. Geologica Belgica, 23/3-4, this volume. https://doi.org/10.20341/gb.2020.017

de Heinzelin de Braucourt, J., 1952. Note sur les coupes de l'écluse Baudouin à Anvers. Bulletin de la Société belge de Géologie, de Paléontologie et d'Hydrologie, 61, 106-108.

de Heinzelin de Braucourt, J., 1955a. Deuxième série d'observations stratigraphiques au Kruisschans. Coupes de l'écluse Baudouin: I.
Analyse stratigraphique. Bulletin de 1'Institut royal des Sciences naturelles de Belgique, Sciences de la Terre, 31/66, 1-29.

de Heinzelin de Braucourt, J., 1955b. Deuxième série d'observations stratigraphiques au Kruisschans. Coupes de l'écluse Baudouin : 2 : Conclusions. Bulletin de l'Institut royal des Sciences naturelles de Belgique, Sciences de la Terre, 31/66, 14 p.

de Heinzelin de Braucourt, J., 1965. Pogonophores fossiles ? Bulletin de la Société belge de Géologie, de Paléontologie et d'Hydrologie, 73, 501-517.

De Meuter, F.J. \& Laga, P.G., 1976. Lithostratigraphy and biostratigraphy based on benthonic foraminifera of the Neogene deposits of Northern Belgium. Bulletin de la Société belge de Géologie, 85/4, 133-152.

De Schepper, S., Head, M.J. \& Louwye, S., 2009. Pliocene dinoflagellate cyst stratigraphy, palaeoecology and sequence stratigraphy of the Tunnel-Canal Dock, Belgium. Geological Magazine, 146/1, 92-112. https://doi.org/10.1017/S0016756808005438

Goolaerts, S., 2000. Sedimentologische, stratigrafische en paleoecologische studie van de Pliocene en Quartaire afzettingen aangetroffen in fase 2 van het Verrebroekdok, provincie OostVlaanderen. Proefschrift Licentiaat Geologie (unpublished Master Thesis), KULeuven, Leuven, 133 p.

Laga, P., 1972. Stratigrafie van de mariene Plio-Pleistocene afzettingen uit de omgeving van Antwerpen met een bijzondere studie van de foraminiferen. Unpublished Ph.D. Thesis, KULeuven, Leuven, 252 p.

Louwye, S., Head, M.J. \& De Schepper, S., 2004. Dinoflagellate cyst stratigraphy and palaeoecology of the Pliocene in northern Belgium, southern North Sea Basin. Geological Magazine, 141/3, 353-378. https://doi.org/10.1017/S0016756804009136

Louwye, S., Deckers, J. \& Vandenberghe, N., 2020. The Pliocene Lillo, Poederlee, Merksplas, Mol and Kieseloolite Formations in northern Belgium: a synthesis. Geologica Belgica, 23/3-4, this volume. https://doi.org/10.20341/gb.2020.016

Schiltz, M., 2020. On the use of CPTs in stratigraphy: recent observations and some illustrative cases. Geologica Belgica, 23/3-4, this volume. https://doi.org/10.20341/gb.2020.019

Van Haren, T., Deckers, J., De Koninck, R., Dirix, K., Hambsch, L. \& Van Baelen, K., in prep. Ondiep geologische 3D lagen- en voxelmodel van de regio Antwerpen. VITO, Mol, VITO-rapport 2019/RMA/R/1985.

Manuscript received 04.10.2020, accepted in revised form 01.12.2020, available online 22.12.2020. 